\title{
ANALYSIS OF PHARMACEUTICAL INSTALLATIONS MANAGEMENT AT KAMBANG HOSPITAL, JAMBI
}

\author{
Fitri Dwiyani'), Amal C. Sjaaf ${ }^{2)}$ \\ 1)Program study Hospital Administration \\ 2)Faculty of Public Health, University of Indonesia
}

\begin{abstract}
Background: Hospital Pharmacy Installation (IFRS) was one of 5 revenue centres as well as being the primary support for the hospital which has full authority in managing various pharmaceutical preparations. Therefore, pharmaceutical supplies require careful and precise management through a one-door system. This study aimed to determine the management system and identify the various problems that exist in the pharmacy installation at Kambang Jambi Hospital.
\end{abstract}

Subjects and Method: This study was a qualitative study conducted on IFRS at Kambang Jambi Hospital from August to September 2020. The data were obtained from primary data in the form of in-depth interviews with stakeholders related to IFRS and field observations, as well as secondary data in the form of document review. The data were collected by in-depth interview guide. The data was reported by 5 Whys Analysis diagram.

Results: Based on field observations at IFRS Kambang Jambi Hospital, it was found that there were still many problems at almost every stage of pharmaceutical supply management starting from planning, procurement, receiving, storage, distribution, control, deletion, recording and reporting, as well as monitoring and evaluation. When the problem is identified more deeply using 5 Whys Analysis, the roots of these various problems are obtained, namely: 1) There has not been an adequate Pharmacy and Therapy Committee (KFT) in the management of the pharmaceutical installation at Kambang Jambi Hospital, 2) The majority of KFT members have assumed structural positions at Kambang Jambi Hospital so that it does not focus on KFT duties, 3) KFT does not regularly hold monthly meetings and evaluations, 4) The ineffective role of SPI at Kambang Jambi Hospital in monitoring and evaluating IFRS performance, 5) SIMRS still depends on outsiders not always standby at the hospital when there are problems.

Conclusion: Re-organized the pharmacy and therapy committee to carry out a continuous review of the hospital formularies to be more effective and minimize medication errors.

Keywords: IFRS, IFRS management, drug procurement, KFT.

\section{Korespondensi:}

Fitri Dwiyani. Postgraduate Student for Hospital Administration Studies, Faculty of Public Health, University of Indonesia, Depok City, West Java. Email: fitridwiyani14@gmail.com. Mobile: 081221005831/081221005831

The $7^{\text {th }}$ International Conference on Public Health Solo, Indonesia, November 18-19, 2020|335 https://doi.org/10.26911/the7thicph.04.20 